\title{
Diversity of segetal flora in crops cultivated in selected farms in Wielkopolska province
}

\author{
Różnorodność segetalna w łanach roślin uprawnych \\ w wybranych gospodarstwach rolnych województwa wielkopolskiego
}

\author{
Jolanta Bojarszczuk*, Janusz Podleśny
}

\section{Summary}

The aim of the study was to evaluate the weed infestation in selected crops cultivated on farms of different arable area in Wielkopolska voivodeship. The assessments of species weed composition and abundance of each species were performed. The structure of weed communities in the cultivated crops was assessed using two ecological indicators: Shannon-Wiener index $\left(\mathrm{H}^{\prime}\right)$ and Simpson domination index (SI). The analysis showed that the species composition of weed communities in the field of cultivated plants differed depending on the farm size and the crop species. The variety of segetal flora associated with crop plants was higher in species of winter forms than spring ones. The weed infestation occurred the most in the fields of triticale and wheat, while the least in barley and cereal mixture. The most weeds in the winter crops were found on the largest farms, while the lowest on the farms up to 20 ha of arable land. The assessment of biological diversity of segetal flora revealed differences between particular groups of farms. The most numerous species of weeds were: Chenopodium album, Centaurea cyanus, Anthemis arvensis, Apera spica-venti, Galium aparine, Fallopia convolvulus and Echinochloa crus-galli.

Key words: segetal flora, crop species, farms, domination index, diversity

\section{Streszczenie}

Celem przeprowadzonych badań była ocena zachwaszczenia w uprawie wybranych gatunków roślin w gospodarstwach zróżnicowanych powierzchnią użytków rolnych położonych w województwie wielkopolskim. Badania obejmowały ocenę składu gatunkowego chwastów oraz liczebności poszczególnych gatunków. Zróżnicowanie zbiorowisk chwastów określono z wykorzystaniem wskaźników ekologicznych, do których zalicza się wskaźnik Shannona-Wienera i wskaźnik różnorodności Simpsona. Przeprowadzona analiza wykazała, że skład gatunkowy zbiorowisk chwastów w łanie uprawianych roślin różnił się w zależności od wielkości gospodarstwa oraz gatunku rośliny uprawnej. Różnorodność flory segetalnej towarzyszącej roślinom uprawnym była większa w gatunkach form ozimych niż jarych. Najbardziej zachwaszczony był łan pszenżyta i pszenicy, natomiast najmniej jęczmienia i mieszanki zbożowej. Najwięcej chwastów w łanach ozimych form roślin uprawnych stwierdzono w gospodarstwach największych obszarowo, natomiast najmniej w gospodarstwach do 20 ha użytków rolnych. Ocena różnorodności biologicznej flory segetalnej wykazała różnice pomiędzy poszczególnymi grupami gospodarstw. Najliczniej występującymi gatunkami chwastów były taksony: Chenopodium album, Centaurea cyanus, Anthemis arvensis, Apera spica-venti, Galium aparine, Fallopia convolvulus oraz Echinochloa crus-galli.

Słowa kluczowe: flora segetalna, gatunki roślin, gospodarstwa, indeks dominacji, różnorodność 


\section{Wstęp / Introduction}

Jednym z warunków uzyskiwania wysokich i dobrych jakościowo plonów roślin uprawnych jest umożliwienie im wzrostu w środowisku wolnym od chwastów. Rośliny niepożądane występujące na polach uprawnych są nieodłącznym składnikiem agrofitocenozy (Dobrzański 2009). Obecność roślin niepożądanych niesie ze sobą konieczność zwiększenia kosztów produkcji (Staniak i wsp. 2011). Skład florystyczny zbiorowiska chwastów, ich liczba i częstotliwość występowania oraz stosunki ilościowe pomiędzy gatunkami są zależne od warunków siedliska, takich jak m.in.: rodzaj gleby, jej wilgotność i zasobność w składniki pokarmowe, poziom i sposób nawożenia, odczyn, warunki termiczne, sposób uprawy roli, gatunki uprawianych roślin (Dobrzański 2007, 2009; Woźnica 2008; Dobrzański i Adamczewski 2009). Celem działań rolnika powinno być zminimalizowanie ujemnych skutków wywołanych stałą obecnością chwastów.

Sposób zwalczania chwastów zależy od prowadzonego systemu produkcji rolnej. W systemie konwencjonalnym regulacja zachwaszczenia przeprowadzana jest głównie z wykorzystaniem herbicydów (Feledyn-Szewczyk i Duer 2006). W systemie ekologicznym, walka $z$ zachwaszczeniem roślin uprawnych najczęściej przebiega poprzez m.in. odpowiednio dobrany płodozmian, zróżnicowaną agrotechnikę, dobór odmian o większej konkurencyjności w stosunku do gatunków niepożądanych, a także stosowanie wsiewek i międzyplonów (Duer 2002). Natomiast integrowany sposób regulacji zachwaszczenia polega na łączeniu efektywnych, bezpiecznych dla środowiska i społecznie akceptowanych metod w celu utrzymania populacji chwastów poniżej progu ekonomicznej szkodliwości (Rola i Rola 2002). Działalność rolnicza może mieć różnoraki wpływ na różnorodność biologiczną. Niektóre praktyki są dla niej zagrożeniem, inne natomiast oddziałują pozytywnie. Do zagrożeń można zaliczyć m.in.: monokultury roślin uprawnych, nadmierną mechanizację i chemizację, nadmierny wypas zwierząt, niewłaściwe wykorzystanie środków ochrony roślin (Giera 2012). Prowadzenie różnego rodzaju praktyk rolniczych może się jednak przyczyniać do zwiększania różnorodności biologicznej w wyniku stosowania zarówno tradycyjnych systemów gospodarowania, jak i nowoczesnych zasad zrównoważonej produkcji rolnej (Berbeć i wsp. 2013).

Celem przeprowadzonych badań była ocena i porównanie różnorodności gatunkowej oraz liczebności roślin segetalnych występujących w uprawie wybranych gatunków roślin w gospodarstwach w województwie wielkopolskim, zróżnicowanych powierzchnią użytków rolnych.

\section{Materiały i metody / Materials and methods}

Podstawę opracowania stanowiły wyniki badań przeprowadzonych w 2017 roku w wybranych gospodarstwach w województwie wielkopolskim (rys. 1). Wyboru gospodarstw dokonano w sposób celowy, przy współpracy z Wielkopolskim Ośrodkiem Doradztwa Rolniczego (WODR) w Poznaniu. Polegało to na wyborze obiektów na podstawie określonych kryteriów zapewniających kontrolę zarówno homogeniczności, jak i zróżnicowania próby. Ocena flory segetalnej badanych upraw przeprowadzana była przez doradców rolnych WODR. Informacje na temat gospodarstw, ich powierzchni, stosowanej agrotechniki, zachwaszczenia wybranych gatunków przeprowadzono metodą ankietową, za pomocą specjalnie przygotowanego w tym celu kwestionariusza wywiadu. Do celów analitycznych dokonano podziału gospodarstw na 5 grup różniących się powierzchnią użytków rolnych: I - do 20, II - od 21 do 30, III - od 31 do 50, IV - od 51 do 100 i V - powyżej 100 ha. Badania wykonano w 39 gospodarstwach (w grupie I - 6, II - 6, III - 9, IV - 9, $\mathrm{V}-9$ gospodarstw) na polach z uprawą różnych gatunków roślin, form ozimych: pszenicy i pszenżyta oraz form jarych: jęczmienia, mieszanki zbożowej i kukurydzy. Ocenę różnorodności gatunkowej chwastów przeprowadzono przed zbiorem roślin metodą wagowo-ramkową z powierzchni $1 \mathrm{~m}^{2}$. Badania obejmowały ocenę składu gatunkowego chwastów oraz liczebności poszczególnych gatunków. W celu przeprowadzania oceny flory segetalnej, na polu z uprawą wybranego gatunku rośliny, wyznaczono w sposób losowy z pominięciem strefy brzegowej

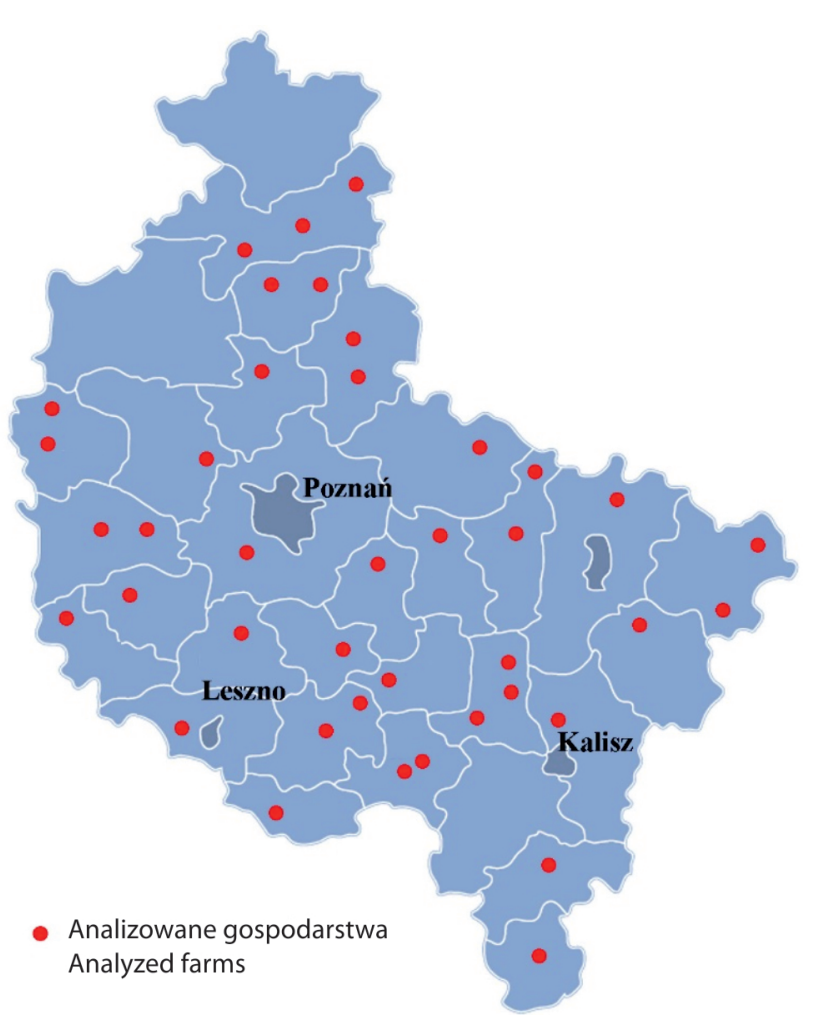

Rys. 1. Lokalizacja analizowanych gospodarstw rolnych na terenie województwa wielkopolskiego

Fig. 1. Location of analyzed farms on the Wielkopolska region 
pola $(10 \mathrm{~m}), 5$ powierzchni badawczych o wielkości $0,5 \mathrm{~m}^{2}$. W badanych gospodarstwach prowadzono ochronę chemiczną przed chwastami. Najczęściej stosowanymi środkami ochrony roślin w badanych gospodarstwach były: Lancet Plus 125 WG, Sekator 125 OD, Metazanex 500 SC, Lintur 75 WG, Puma Universal 069 EW, Chwastox Turbo 340 SL, Chwastox Trio 540 SL. Wyznaczono również dwa wskaźniki ekologiczne: indeks różnorodności Shannona-Wienera (H') oraz indeks dominacji Simpsona (SI). Indeks Shanonna-Wienera jest wskaźnikiem ogólnej różnorodności gatunkowej. Uzależniony jest od liczby gatunków oraz ich wzajemnych proporcji ilościowych i obliczany według wzoru Shannona-Wienera i Weavera (Zanin i wsp. 1992):

$$
\mathrm{H}^{\prime}=-\sum \mathrm{Pi} \ln \mathrm{Pi}
$$

Pi - stosunek liczby chwastów danego gatunku do ogólnej liczebności chwastów na powierzchni próbnej.

Indeks Simpsona (SI) jest wskaźnikiem stosowanym do oszacowania różnorodności biologicznej siedlisk. Określa prawdopodobieństwo wylosowania dwóch osobników należących do tego samego gatunku. Uwzględnia liczbę gatunków oraz względną liczebność każdego gatunku i opisany jest wzorem Simpsona (Zanin i wsp. 1992):

$$
\mathrm{SI}=\sum \mathrm{Pi}^{2}
$$

$\mathrm{Pi}$ - stosunek liczby chwastów danego gatunku do ogólnej liczebności chwastów na powierzchni próbnej.

\section{Wyniki i dyskusja / Results and discussion}

Średnia powierzchnia gospodarstwa, dla grupy w której prowadzono monitoring różnorodności biologicznej wynosiła 74,3 ha i była 5-krotnie większa od średniej powierzchni gospodarstwa w województwie wielkopolskim (GUS 2018) (tab. 1). Średnia powierzchnia użytków rolnych, będących w posiadaniu badanych gospodarstw wynosiła 71,3 ha. We wszystkich gospodarstwach w strukturze użytków rolnych dominowały grunty orne, średnio 90\%. Największą powierzchnią trwałych użytków zielonych cechowały się gospodarstwa w grupie V (powyżej 100 ha). Średnio w objętych analizą gospodarstwach udział dzierżawionych użytków rolnych wynosił 20\%, przy czym najwyższym wskaźnikiem cechowały się gospodarstwa powyżej 100 ha (29\%). Gospodarstwa te w większości prowadziły intensywną produkcję rolną. Zdecydowana większość badanych gospodarstw prowadziła produkcję towarową.

W strukturze zasiewów znaczący udział stanowiła kukurydza (średnio 23\%), pszenica ozima i pszenżyto ozime (odpowiednio 19 i 20\%) oraz jęczmień jary

Tabela 1. Charakterystyka badanych gospodarstw

\begin{tabular}{|c|c|c|c|c|c|c|}
\hline \multirow{2}{*}{$\begin{array}{l}\text { Wyszczególnienie } \\
\text { Specification }\end{array}$} & \multicolumn{5}{|c|}{$\begin{array}{l}\text { Grupa obszarowa gospodarstw } \\
\text { Group of area farm }\end{array}$} & \multirow{2}{*}{$\begin{array}{l}\text { Średnio } \\
\text { Mean }\end{array}$} \\
\hline & $10-20$ & $21-30$ & $31-50$ & $51-100$ & $>100$ & \\
\hline $\begin{array}{l}\text { Średnia powierzchnia gospodarstwa } \\
\text { Average farm surface [ha] }\end{array}$ & 16,94 & 27,37 & 39,86 & 73,17 & 214,32 & 74,33 \\
\hline $\begin{array}{l}\text { Średnia powierzchnia użytków rolnych } \\
\text { w gospodarstwie, w tym: } \\
\text { Average usable agricultural lands surface } \\
\text { on a farm, including: [ha, \%] }\end{array}$ & $\begin{array}{c}16,38 \\
(100 \%)\end{array}$ & $\begin{array}{c}26,09 \\
(100 \%)\end{array}$ & $\begin{array}{c}36,82 \\
(100 \%)\end{array}$ & $\begin{array}{l}68,78 \\
(100 \%)\end{array}$ & $\begin{array}{l}208,59 \\
(100 \%)\end{array}$ & $\begin{array}{c}71,33 \\
(100 \%)\end{array}$ \\
\hline Grunty orne - Arable lands [ha, \%] & $\begin{array}{c}14,06 \\
(83,8 \%)\end{array}$ & $\begin{array}{c}23,73 \\
(91,1 \%)\end{array}$ & $\begin{array}{c}33,29 \\
(90,1 \%)\end{array}$ & $\begin{array}{c}64,09 \\
(92,6 \%)\end{array}$ & $\begin{array}{c}198,21 \\
(94,1 \%)\end{array}$ & $\begin{array}{c}66,68 \\
(90,3 \%)\end{array}$ \\
\hline $\begin{array}{l}\text { Trwałe użytki zielone } \\
\text { Permanent grasslands [ha, \%] }\end{array}$ & $\begin{array}{c}2,32 \\
(16,2 \%) \\
\end{array}$ & $\begin{array}{c}2,12 \\
(8,9 \%) \\
\end{array}$ & $\begin{array}{c}4,36 \\
(9,8 \%) \\
\end{array}$ & $\begin{array}{c}5,36 \\
(7,3 \%) \\
\end{array}$ & $\begin{array}{l}14,13 \\
(5,3 \%) \\
\end{array}$ & $\begin{array}{c}5,66 \\
(9,5 \%) \\
\end{array}$ \\
\hline $\begin{array}{l}\text { Plantacje sadownicze i jagodowe } \\
\text { Orchards and berry plantations [ha, \%] }\end{array}$ & $\begin{array}{l}0,00 \\
(0 \%)\end{array}$ & $\begin{array}{l}0,00 \\
(0 \%) \\
\end{array}$ & $\begin{array}{l}0,00 \\
(0 \%)\end{array}$ & $\begin{array}{c}0,31 \\
(0,1 \%) \\
\end{array}$ & $\begin{array}{l}0,00 \\
(0 \%) \\
\end{array}$ & $\begin{array}{l}0,06 \\
(0 \%) \\
\end{array}$ \\
\hline Ugory - Fallow lands [ha, \%] & $\begin{array}{l}0,00 \\
(0 \%)\end{array}$ & $\begin{array}{l}0,00 \\
(0 \%)\end{array}$ & $\begin{array}{c}0,30 \\
(0,1 \%) \\
\end{array}$ & $\begin{array}{l}0,00 \\
(0 \%) \\
\end{array}$ & $\begin{array}{c}5,06 \\
(0,3 \%) \\
\end{array}$ & $\begin{array}{c}1,07 \\
(0,1 \%) \\
\end{array}$ \\
\hline $\begin{array}{l}\text { Inne: lasy, stawy, pod siedliskiem } \\
\text { Other: forests, ponds, in the vicinity } \\
\text { of the farm [ha] }\end{array}$ & 0,53 & 1,82 & 6,30 & 4,45 & 7,09 & 4,04 \\
\hline $\begin{array}{l}\text { Udział użytków rolnych dzierżawionych } \\
\text { Share of agricultural lands tenanced [\%] }\end{array}$ & 14,2 & 11,3 & 24,1 & 20,9 & 29,0 & 19,9 \\
\hline
\end{tabular}

Table 1. Characteristic of assessed farms

Źródło: opracowanie własne - Source: own elaboration 
i mieszanka zbożowa (po 17\%) (tab. 2). Z tego względu te gatunki roślin zostały uwzględnione w badaniach.

Analiza dotycząca sposobu regulacji zachwaszczenia prowadzonych upraw wykazała, że w gospodarstwach mniejszych obszarowo (do 20 ha) decyzję o wykonaniu zabiegu podejmowano głównie w oparciu o własne obserwacje (tab. 3). Natomiast w gospodarstwach o większej powierzchni (powyżej 31 ha) głównym wyznacznikiem decydującym o wyborze pestycydu była jego skuteczność działania. Ponadto w $11 \%$ tych gospodarstw decyzja o wykonaniu zabiegu podejmowana była przez rolnika w oparciu o próg ekonomicznej szkodliwości, a więc w sytuacji gdzie nasilenie agrofaga było na tyle duże, że wykonanie zabiegu było opłacalne ze względu na możliwe straty wynikające z obniżenia plonu. Właściciele większych obszarowo gospodarstw decyzję o wykonaniu zabiegu podejmowali w oparciu o profesjonalne doradztwo.

Skuteczność przeprowadzonych zabiegów ochrony roślin w badanych gospodarstwach określono jako bardzo wysoką, bowiem przekraczającą $86 \%$ niezależnie od powierzchni użytków rolnych (tab. 3). Można zatem uznać, że zabiegi chemiczne stosowane w celu ograniczenia zachwaszczenia analizowanych gatunków roślin uprawnych były wykonywane w analizowanych gospodarstwach w miarę poprawnie, z zachowaniem najważniejszych zasad ochrony chemicznej i w warunkach pogodowych sprzyjających ich dużej skuteczności.

Badając zachwaszczenie pól uprawnych zwraca się zazwyczaj uwagę na liczebność, masę chwastów i pokrycie przez nie powierzchni gleby. Ważna jest również ich różnorodność oraz dominacja poszczególnych gatunków (Stupnicka-Rodzynkiewicz i wsp. 2004).

W badanych gospodarstwach objętych monitoringiem bioróżnorodności stwierdzono ogółem od 5 do 17 gatunków chwastów towarzyszących uprawom. Skład gatunkowy zbiorowisk chwastów różnił się w zależności od wielkości gospodarstwa oraz gatunku rośliny uprawnej. Najwięcej gatunków chwastów rozpoznano w łanie pszenicy ozimej i kukurydzy uprawianych w gospodarstwach o powierzchni powyżej 100 ha (odpowiednio 17 i 12 gatunków) (tab. 4), w łanie pszenżyta ozimego i mieszanki zbożowej w gospodarstwach o powierzchni od 31-50 ha (odpowiednio

Tabela 2. Powierzchnia i udział w strukturze zasiewów badanych gatunków roślin uprawnych [ha, \%]

Table 2. The cultivation area and share in cropping pattern of assessed plant species [ha, \%]

\begin{tabular}{l|c|c|c|c|c|c}
\hline \multirow{2}{*}{$\begin{array}{c}\text { Wyszczególnienie } \\
\text { Specification }\end{array}$} & \multicolumn{4}{c|}{$\begin{array}{c}\text { Grupa obszarowa gospodarstw } \\
\text { Group of area farm }\end{array}$} & $\begin{array}{c}\text { Średnio } \\
\text { Mean }\end{array}$ \\
\cline { 2 - 7 } & $10-20$ & $21-30$ & $31-50$ & $51-100$ & $>100$ & \\
\hline Pszenica ozima - Winter wheat & $3,0(21,4 \%)$ & $2,9(12,2 \%)$ & $7,7(23,0 \%)$ & $8,2(12,6 \%)$ & $55,6(28,1 \%)$ & $15,5(19,5 \%)$ \\
\hline Pszenżyto ozime - Winter triticale & $3,6(25,7 \%)$ & $4,4(18,7 \%)$ & $8,1(24,4 \%)$ & $8,0(12,5 \%)$ & $36,7(18,5 \%)$ & $12,2(20,0 \%)$ \\
\hline Jęczmień jary - Spring barley & $3,5(25,0 \%)$ & $2,8(11,6 \%)$ & $5,7(17,0 \%)$ & $13,6(21,3 \%)$ & $23,9(12,1 \%)$ & $9,9(17,4 \%)$ \\
\hline Mieszanka zbożowa - Cereals mixture & $2,2(15,7 \%)$ & $7,0(29,5 \%)$ & $6,4(19,3 \%)$ & $10,0(15,0 \%)$ & $17,2(8,7 \%)$ & $8,6(17,6 \%)$ \\
\hline Kukurydza - Maize & $2,3(16,4 \%)$ & $6,6(27,8 \%)$ & $4,4(13,3 \%)$ & $24,0(37,1 \%)$ & $43,7(22,1 \%)$ & $16,2(23,3 \%)$ \\
\hline
\end{tabular}

Źródło: opracowanie własne - Source: own elaboration

Tabela 3. Sposób regulacji zachwaszczenia w badanych gospodarstwach

Table 3. Methods of regulation weed infestation in tested farms

\begin{tabular}{|c|c|c|c|c|c|c|}
\hline \multirow{2}{*}{$\begin{array}{l}\text { Wyszczególnienie } \\
\text { Specification }\end{array}$} & \multicolumn{5}{|c|}{$\begin{array}{l}\text { Grupa obszarowa gospodarstw } \\
\text { Area groups of farms }\end{array}$} & \multirow{2}{*}{$\begin{array}{l}\text { Średnio } \\
\text { Mean }\end{array}$} \\
\hline & I & II & III & IV & $\mathrm{V}$ & \\
\hline \multicolumn{7}{|c|}{ Podstawa wyboru środka ochrony roślin - The basis for selection of pesticide [\%] } \\
\hline Skuteczność działania - Effectiveness & 10 & 20 & 55 & 65 & 80 & 46 \\
\hline Cena-Price & 90 & 80 & 55 & 35 & 20 & 56 \\
\hline Próg szkodliwości - Harmfulness threshold & 0 & 0 & 15 & 20 & 20 & 11 \\
\hline \multicolumn{7}{|c|}{ Podstawa decyzji - Basis for a decision [\%] } \\
\hline Obserwacje własne - Own observations & 100 & 100 & 75 & 80 & 80 & 87 \\
\hline Profesjonalne doradztwo - Professional consulting services & 0 & 50 & 35 & 70 & 70 & 45 \\
\hline Skuteczność zabiegu - Effectiveness of the treatment & 90 & 80 & 80 & 86 & 95 & 86 \\
\hline
\end{tabular}

Źródło: opracowanie własne - Source: own elaboration 
Tabela 4. Liczba gatunków chwastów [szt./ $\mathrm{m}^{2}$ ] w uprawie badanych gatunków roślin oraz ich udział w strukturze chwastów ogółem [\%] Table 4. Number of weeds [units $/ \mathrm{m}^{2}$ ] in the cultivation of assessed plant species and their share in the structure of weeds total number [\%]

\begin{tabular}{|c|c|c|c|c|c|c|}
\hline \multirow{2}{*}{ Wyszczególnienie - Specification } & \multicolumn{5}{|c|}{$\begin{array}{c}\text { Grupa obszarowa gospodarstw } \\
\text { Group of area farm }\end{array}$} & \multirow{2}{*}{$\begin{array}{l}\text { Średnio } \\
\text { Mean }\end{array}$} \\
\hline & $10-20$ & $21-30$ & $31-50$ & $51-100$ & $>100$ & \\
\hline \multicolumn{7}{|c|}{ Pszenica ozima - Winter wheat } \\
\hline $\begin{array}{l}\text { Chwasty jednoliścienne [szt./m², \%] } \\
\left.\text { Monocotyledonous [units } / \mathrm{m}^{2}, \%\right]\end{array}$ & - & $\begin{array}{c}8 \\
(13,1 \%) \\
\end{array}$ & $\begin{array}{c}17 \\
(24,3 \%)\end{array}$ & $\begin{array}{c}39 \\
(53,4 \%)\end{array}$ & $\begin{array}{c}27 \\
(25,2 \%)\end{array}$ & $\begin{array}{c}18,2 \\
(23,2 \%)\end{array}$ \\
\hline $\begin{array}{l}\text { Chwasty dwuliścienne }\left[\mathrm{szt} . / \mathrm{m}^{2}, \%\right] \\
\left.\text { Dicotyledonous [units } / \mathrm{m}^{2}, \%\right]\end{array}$ & $\begin{array}{c}40 \\
(100 \%)\end{array}$ & $\begin{array}{c}53 \\
(86,9 \%)\end{array}$ & $\begin{array}{c}53 \\
(75,7 \%)\end{array}$ & $\begin{array}{c}34 \\
(46,6 \%)\end{array}$ & $\begin{array}{c}80 \\
(74,8 \%)\end{array}$ & $\begin{array}{c}52 \\
(76,8 \%)\end{array}$ \\
\hline $\begin{array}{l}\left.\text { Liczba gatunków [szt. } / \mathrm{m}^{2}\right] \\
\left.\text { Number of species [units } / \mathrm{m}^{2}\right]\end{array}$ & 5 & 9 & 12 & 9 & 17 & 10,4 \\
\hline \multicolumn{7}{|c|}{ Pszenżyto ozime - Winter triticale } \\
\hline $\begin{array}{l}\text { Chwasty jednoliścienne }\left[\mathrm{szt} . / \mathrm{m}^{2}, \%\right] \\
\left.\text { Monocotyledonous [units } / \mathrm{m}^{2}, \%\right]\end{array}$ & - & $\begin{array}{c}12 \\
(18,8 \%)\end{array}$ & $\begin{array}{c}76 \\
(49,7 \%)\end{array}$ & $\begin{array}{c}7 \\
(13,5 \%)\end{array}$ & $\begin{array}{c}25 \\
(37,3 \%)\end{array}$ & $\begin{array}{c}24 \\
(23,8 \%)\end{array}$ \\
\hline $\begin{array}{l}\text { Chwasty dwuliścienne }\left[\mathrm{szt} . / \mathrm{m}^{2}, \% \text { ] }\right. \\
\text { Dicotyledonous [units } / \mathrm{m}^{2}, \% \text { ] }\end{array}$ & $\begin{array}{c}33 \\
(100 \%) \\
\end{array}$ & $\begin{array}{c}52 \\
(81,3 \%) \\
\end{array}$ & $\begin{array}{c}77 \\
(50,3 \%)\end{array}$ & $\begin{array}{c}45 \\
(86,5 \%)\end{array}$ & $\begin{array}{c}42 \\
(62,7 \%)\end{array}$ & $\begin{array}{c}49,8 \\
(76,2 \%)\end{array}$ \\
\hline $\begin{array}{l}\text { Liczba gatunków }\left[\mathrm{szt} . / \mathrm{m}^{2}\right] \\
\text { Number of species }\left[\text { units } / \mathrm{m}^{2}\right]\end{array}$ & 9 & 8 & 12 & 9 & 8 & 9,2 \\
\hline \multicolumn{7}{|c|}{ Jęczmień jary - Spring barley } \\
\hline $\begin{array}{l}\text { Chwasty jednoliścienne }\left[\mathrm{szt} . / \mathrm{m}^{2}, \%\right] \\
\text { Monocotyledonous }\left[\text { units } / \mathrm{m}^{2}, \%\right]\end{array}$ & $\begin{array}{c}6 \\
(12,0 \%)\end{array}$ & $\begin{array}{c}2 \\
(9,5 \%)\end{array}$ & $\begin{array}{c}15 \\
(48,4 \%)\end{array}$ & $\begin{array}{c}7 \\
(18,9 \%)\end{array}$ & - & $\begin{array}{c}6 \\
(17,8 \%)\end{array}$ \\
\hline $\begin{array}{l}\text { Chwasty dwuliścienne }\left[\mathrm{szt} . / \mathrm{m}^{2}, \%\right] \\
\left.\text { Dicotyledonous [units } / \mathrm{m}^{2}, \%\right]\end{array}$ & $\begin{array}{c}44 \\
(88,0 \%)\end{array}$ & $\begin{array}{c}19 \\
(90,5 \%)\end{array}$ & $\begin{array}{c}16 \\
(51,6 \%)\end{array}$ & $\begin{array}{c}30 \\
(81,1 \%)\end{array}$ & $\begin{array}{c}28 \\
(100,0 \%)\end{array}$ & $\begin{array}{c}27,4 \\
(82,2 \%)\end{array}$ \\
\hline $\begin{array}{l}\left.\text { Liczba gatunków [szt. } / \mathrm{m}^{2}\right] \\
\left.\text { Number of species [units } / \mathrm{m}^{2}\right]\end{array}$ & 11 & 9 & 7 & 10 & 7 & 8,8 \\
\hline \multicolumn{7}{|c|}{ Mieszanka zbożowa - Cereal mixture } \\
\hline $\begin{array}{l}\text { Chwasty jednoliścienne }\left[\mathrm{szt} . / \mathrm{m}^{2}, \%\right] \\
\left.\text { Monocotyledonous [units } / \mathrm{m}^{2}, \%\right]\end{array}$ & $\begin{array}{c}2 \\
(4,7 \%) \\
\end{array}$ & - & $\begin{array}{c}10 \\
(8,1 \%) \\
\end{array}$ & $\begin{array}{c}10 \\
(24,4 \%)\end{array}$ & - & $\begin{array}{c}4,4 \\
(7,5 \%) \\
\end{array}$ \\
\hline $\begin{array}{l}\text { Chwasty dwuliścienne }\left[\mathrm{szt} . / \mathrm{m}^{2}, \%\right] \\
\left.\text { Dicotyledonous [units } / \mathrm{m}^{2}, \%\right]\end{array}$ & $\begin{array}{c}41 \\
(95,3 \%) \\
\end{array}$ & $\begin{array}{c}32 \\
(100,0 \%) \\
\end{array}$ & $\begin{array}{c}114 \\
(91,1 \%) \\
\end{array}$ & $\begin{array}{c}31 \\
(75,6 \%)\end{array}$ & $\begin{array}{c}25 \\
(100,0 \%) \\
\end{array}$ & $\begin{array}{c}48,6 \\
(92,5 \%) \\
\end{array}$ \\
\hline $\begin{array}{l}\left.\text { Liczba gatunków [szt. } / \mathrm{m}^{2}\right] \\
\left.\text { Number of species [units } / \mathrm{m}^{2}\right]\end{array}$ & 9 & 6 & 11 & 6 & 5 & 7,4 \\
\hline \multicolumn{7}{|c|}{ Kukurydza - Maize } \\
\hline $\begin{array}{l}\left.\text { Chwasty jednoliścienne [szt. } / \mathrm{m}^{2}, \%\right] \\
\left.\text { Monocotyledonous [units } / \mathrm{m}^{2}, \%\right]\end{array}$ & $\begin{array}{c}1 \\
(2,4 \%)\end{array}$ & $\begin{array}{c}25 \\
(44,6 \%) \\
\end{array}$ & $\begin{array}{c}23 \\
(46,0 \%) \\
\end{array}$ & $\begin{array}{c}19 \\
(23,2 \%)\end{array}$ & $\begin{array}{c}9 \\
(11,5 \%) \\
\end{array}$ & $\begin{array}{c}15,4 \\
(25,5 \%) \\
\end{array}$ \\
\hline $\begin{array}{l}\text { Chwasty dwuliścienne }\left[\mathrm{szt} . / \mathrm{m}^{2}, \%\right] \\
\left.\text { Dicotyledonous [units } / \mathrm{m}^{2}, \%\right]\end{array}$ & $\begin{array}{c}40 \\
(97,6 \%) \\
\end{array}$ & $\begin{array}{c}31 \\
(55,4 \%)\end{array}$ & $\begin{array}{c}27 \\
(54,0 \%) \\
\end{array}$ & $\begin{array}{c}63 \\
(76,8 \%) \\
\end{array}$ & $\begin{array}{c}69 \\
(88,5 \%) \\
\end{array}$ & $\begin{array}{c}46 \\
(74,5 \%) \\
\end{array}$ \\
\hline $\begin{array}{l}\text { Liczba gatunków }\left[\mathrm{szt} . / \mathrm{m}^{2}\right] \\
\left.\text { Number of species [units } / \mathrm{m}^{2}\right]\end{array}$ & 9 & 6 & 8 & 11 & 12 & 9,2 \\
\hline
\end{tabular}

Źródło: opracowanie własne - Source: own elaboration

12 i 11 gatunków) (tab. 4), natomiast w uprawie jęczmienia jarego w gospodarstwach o powierzchni do 20 ha (11 gatunków) (tab. 4).

Niezależnie od rodzaju uprawy bardziej liczne były gatunki dwuliścienne, które stanowiły w ogólnej liczebności chwastów średnio od 76,2\% w uprawie pszenżyta ozimego do $92,5 \%$ w uprawie mieszanki zbożowej (tab. 4). Udział ich był zróżnicowany w zależności od wielkości gospodarstwa, wyrażonego powierzchnią użytków rolnych. W uprawie pszenicy w gospodarstwach o powierzchni w zakresie 51-100 ha użytków rolnych, udział chwastów dwuliściennych był niższy od średniej dla wszystkich gospodarstw i wyniósł $46,6 \%$, co wynikało z dużego udziału chwastów jednoliściennych (Apera spica-venti i Avena fatua) (tab. 5). W łanach pszenżyta ozimego, jęczmienia jarego i kukurydzy w gospodarstwach o powierzchni w zakresie 31-50 ha, stwierdzono udział chwastów dwuliściennych odpowiednio o 34,37 i 27\% niższy niż średnio dla wszystkich gospodarstw (tab. 6, 7, 9), ze względu na duży udział przedstawicieli gatunków 
Tabela 5. Skład gatunkowy i liczebność chwastów w łanie pszenicy ozimej w gospodarstwach zróżnicowanych powierzchnią użytków rolnych $\left[\mathrm{szt} . / \mathrm{m}^{2}\right]$

Table 5. Weed species composition and number of weeds in winter wheat in farms differentiated agricultural acreage [number $\left./ \mathrm{m}^{2}\right]$

\begin{tabular}{l|c|c|c|c|c|c}
\hline \multirow{2}{*}{ Gatunek chwastu - Weed species } & \multicolumn{4}{|c|}{ Grupa obszarowa gospodarstw - Group of area farm } & \multirow{2}{*}{$\begin{array}{c}\text { Średnio } \\
\text { Mean }\end{array}$} \\
\cline { 2 - 6 } & $10-20$ & $21-30$ & $31-50$ & $51-100$ & $>100$ & \\
\hline
\end{tabular}

Chwasty jednoliścienne - Monocotyledonous

\begin{tabular}{l|c|c|c|c|c|c}
\hline Chwastnica jednostronna - Echinochloa crus-galli & - & - & - & - & 7 & 1,4 \\
\hline Miotła zbożowa-Apera spica-venti & - & 8 & 17 & 7 & 5 & 7,4 \\
\hline Owies głuchy - Avena fatua & - & - & - & 32 & 5 & 7,4 \\
\hline Perz właściwy - Elymus repens & - & - & - & - & 10 & 2,0 \\
\hline
\end{tabular}

Perz właściwy - Elymus repens

Chwasty dwuliścienne - Dicotyledonous

\begin{tabular}{|c|c|c|c|c|c|c|}
\hline Babka zwyczajna - Plantago major & - & - & 4 & - & - & 0,8 \\
\hline Bodziszek porozcinany - Geranium dissectum & 8 & - & - & - & - & 1,6 \\
\hline Chaber bławatek - Centaurea cyanus & - & 10 & 4 & 5 & 5 & 4,8 \\
\hline Fiołek polny - Viola arvensis & - & - & - & 4 & 15 & 3,8 \\
\hline Gwiazdnica pospolita - Stellaria media & - & 8 & 10 & - & 4 & 4,4 \\
\hline Jasnota purpurowa - Lamium purpureum & - & 4 & - & 1 & 5 & 2,0 \\
\hline Komosa biała - Chenopodium album & 10 & 8 & 6 & - & 4 & 5,6 \\
\hline Mak polny - Papaver rhoeas & - & - & 6 & 2 & 3 & 2,2 \\
\hline Maruna bezwonna - Matricaria maritima subsp. inodora & - & - & 1 & - & - & 0,2 \\
\hline Przetacznik perski - Veronica persica & - & - & 6 & - & 5 & 2,2 \\
\hline Przymiotno kanadyjskie - Erigeron canadensis & 5 & - & - & - & - & 1,0 \\
\hline Przytulia czepna - Galium aparine & - & 8 & 3 & 7 & 3 & 4,2 \\
\hline Rdest powojowy - Fallopia convolvulus & 7 & - & - & - & 3 & 2,0 \\
\hline Rumian polny - Anthemis arvensis & 10 & 4 & 4 & 5 & 4 & 5,4 \\
\hline Szarłat szorstki - Amaranthus retroflexus & - & - & - & - & 2 & 0,4 \\
\hline Tasznik pospolity - Capsella bursa-pastoris & - & 5 & 8 & - & 2 & 3,0 \\
\hline Tobołki polne - Thlaspi arvense & - & 6 & 1 & - & - & 1,4 \\
\hline Żółtlica drobnokwiatowa - Galinsoga parviflora & - & - & - & 10 & 25 & 7,0 \\
\hline Razem - Total & 40 & 61 & 70 & 73 & 107 & 70,2 \\
\hline
\end{tabular}

Źródło: opracowanie własne - Source: own elaboration

jednoliściennych, w uprawie jęczmienia: A. spica-venti, w uprawie pszenżyta ozimego dodatkowo Echinochloa crus-galli i Elymus repens, zaś w uprawie kukurydzy - E. crus-galli.

Skład gatunkowy zbiorowisk chwastów różnił się w zależności od powierzchni gospodarstwa oraz gatunku rośliny uprawnej. Bogactwo gatunkowe flory segetalnej form ozimych uprawianych gatunków roślin było większe niż w uprawie roślin form jarych. Stwierdzono istotnie większą średnią liczbę gatunków chwastów w łanie zbóż ozimych.

Najbardziej zachwaszczona była uprawa pszenicy i pszenżyta, w których stwierdzono średnio odpowiednio 70 i 74 sztuki chwastów na jednostce powierzchni (tab. 5, 6), najmniej zaś uprawa jęczmienia, gdzie zanotowano 34 sztuki chwastów na powierzchni $1 \mathrm{~m}^{2}$ (tab. 7). Natomiast w łanach mieszanki zbożowej i kukurydzy stwierdzono odpowiednio średnio 53 i 61 sztuk chwastów na jednostce powierzchni (tab. 8, 9).

Najwięcej taksonów chwastów w łanie pszenicy ozimej na jednostce powierzchni stwierdzono w gospodarstwach powyżej 100 ha użytków rolnych (107 szt./m²), natomiast najmniej w gospodarstwach do 20 ha użytków rolnych $\left(40 \mathrm{szt} . / \mathrm{m}^{2}\right)$. Podobne wyniki uzyskała Feledyn-Szewczyk (2012) wykazując, że pszenica jest przedstawicielem zbóż ozimych charakteryzującym się największym zachwaszczeniem. W badaniach tej autorki zanotowano średnio 82 sztuki chwastów na $1 \mathrm{~m}^{2}$ powierzchni. We wcześniejszych badaniach Bojarszczuk i wsp. (2018) stwierdzili, że spośród ocenianych gatunków najbardziej zachwaszczona była pszenica ozima, w której stwierdzono 
Tabela 6. Różnorodność gatunkowa i liczebność chwastów w łanie pszenżyta ozimego w gospodarstwach zróżnicowanych powierzchnią użytków rolnych $\left[\mathrm{szt} . / \mathrm{m}^{2}\right]$

Table 6. Weed species composition and number of weeds in winter triticale in farms differentiated agricultural acreage [number $\left./ \mathrm{m}^{2}\right]$

\begin{tabular}{|c|c|c|c|c|c|c|}
\hline \multirow{2}{*}{ Gatunek - Weed species } & \multicolumn{5}{|c|}{ Grupa obszarowa gospodarstw - Group of area farm } & \multirow{2}{*}{$\begin{array}{c}\text { Średnio } \\
\text { Mean }\end{array}$} \\
\hline & $10-20$ & $21-30$ & $31-50$ & $51-100$ & $>100$ & \\
\hline \multicolumn{7}{|c|}{ Chwasty jednoliścienne - Monocotyledonous } \\
\hline Chwastnica jednostronna - Echinochloa crus-galli & - & - & 40 & - & 10 & 10,0 \\
\hline Miotła zbożowa - Apera spica-venti & - & 12 & 21 & 7 & 15 & 11,0 \\
\hline Perz właściwy - Elymus repens & - & - & 15 & - & - & 3,0 \\
\hline \multicolumn{7}{|c|}{ Chwasty dwuliścienne - Dicotyledonous } \\
\hline Bodziszek porozcinany - Geranium dissectum & 8 & - & - & - & - & 1,6 \\
\hline Chaber bławatek - Centaurea cyanus & 1 & 6 & 2 & 5 & 5 & 3,8 \\
\hline Fiołek polny - Viola arvensis & 1 & - & 2 & 4 & 15 & 4,4 \\
\hline Gwiazdnica pospolita - Stellaria media & - & 8 & 10 & 1 & - & 3,8 \\
\hline Komosa biała - Chenopodium album & 7 & 9 & 1 & 2 & 3 & 4,4 \\
\hline Mak polny - Papaver rhoeas & - & - & - & 11 & 5 & 3,2 \\
\hline Maruna bezwonna - Matricaria maritima subsp. inodora & 1 & - & - & - & - & 0,2 \\
\hline Ostrożeń polny - Cirsium arvense & 1 & - & - & - & - & 0,2 \\
\hline Przetacznik perski - Veronica persica & - & 7 & 10 & - & - & 3,4 \\
\hline Przymiotno kanadyjskie - Erigeron canadensis & 5 & - & - & - & - & 1,0 \\
\hline Przytulia czepna - Galium aparine & - & 6 & 6 & 7 & - & 3,8 \\
\hline Rdest powojowy - Fallopia convolvulus & 7 & 8 & - & - & - & 3,0 \\
\hline Rumian polny - Anthemis arvensis & 10 & 8 & 38 & 5 & - & 12,2 \\
\hline Szarłat szorstki - Amaranthus retroflexus & - & - & 1 & - & - & 0,2 \\
\hline Tasznik pospolity - Capsella bursa-pastoris & - & - & 7 & - & 10 & 3,4 \\
\hline Tobołki polne - Thlaspi arvense & - & - & - & - & 4 & 0,8 \\
\hline Żółtlica drobnokwiatowa - Galinsoga parviflora & - & - & - & 10 & - & 2,0 \\
\hline Razem - Total & 33 & 64 & 153 & 52 & 67 & 73,8 \\
\hline
\end{tabular}

Źródło: opracowanie własne - Source: own elaboration

średnio 69 sztuk chwastów na jednostce powierzchni. W badaniach własnych największą liczebność chwastów w uprawie pszenżyta ozimego wykazano w gospodarstwach o powierzchni w zakresie $31-50$ ha (153 sztuki). Natomiast najmniej chwastów niepożądanych na jednostce powierzchni stwierdzono w gospodarstwach o powierzchni do 20 ha (33 sztuki).

Odwrotne zależności stwierdzono w uprawie jarych form roślin zbożowych. W łanie jęczmienia i mieszanki zbożowej, najmniejszą liczebność gatunków niepożądanych zanotowano w gospodarstwach największych obszarowo (odpowiednio 28 i $25 \mathrm{szt} . / \mathrm{m}^{2}$ ).

Analizując skład florystyczny stwierdzono, że w uprawach pszenicy ozimej i pszenżyta ozimego najliczniej występowały następujące taksony chwastów dwuliściennych: Chenopodium album, Centaurea cyanus, Anthemis arvensis oraz chwastów jednoliściennych: A. spica-venti, która stanowiła 10\% populacji wszystkich wystę- pujących chwastów. W uprawie jęczmienia jarego najliczniej występującymi gatunkami niepożądanymi, niezależnie od wielkości gospodarstwa były: Galium aparine oraz C. cyanus. W badaniach Orzecha i wsp. (2011) w zasiewach jęczmienia jarego uprawianego w systemie tradycyjnym, szczególnie licznie występowało 5 taksonów chwastów: Capsella bursa-pastoris, Cirsium arvense, Stellaria media, Sonchus arvensis oraz Ch. album. W łanie mieszanki zbożowej dominowały głównie $G$. aparine, Fallopia convolvulus oraz C. cyanus, stanowiąc średnio 37\% całej populacji gatunków niepożądanych. Gatunkami towarzyszącymi w uprawie kukurydzy były głównie: Ch. album i E. crus-galli.

Badania Liszki-Podkowy i Sowińskiego (2009) wykazały, że sposób pielęgnacji i konkurencja wpływają na zmianę składu gatunkowego chwastów. W badaniach Waligóry i wsp. (2009) nad sposobami pielęgnacji kukurydzy cukrowej w województwie wielkopolskim 
Tabela 7. Różnorodność gatunkowa chwastów w łanie jęczmienia jarego w gospodarstwach zróżnicowanych powierzchnią użytków rolnych $\left[\mathrm{szt} . / \mathrm{m}^{2}\right]$

Table 7. Weed species composition and number of weeds in spring barley in farms differentiated on agricultural acreage [number $\left./ \mathrm{m}^{2}\right]$

Gatunek - Weed species

\begin{tabular}{|c|c|c|c|c|c|}
\hline \multicolumn{4}{|c|}{ Grupa obszarowa gospodarstw - Group of area farm } & \multirow{2}{*}{$\begin{array}{c}\text { Średnio } \\
\text { Mean }\end{array}$} \\
\hline $10-20$ & $21-30$ & $31-50$ & $51-100$ & $>100$ & \\
\hline
\end{tabular}

Chwasty jednoliścienne - Monocotyledonous

\begin{tabular}{|c|c|c|c|c|c|c|}
\hline Chwastnica jednostronna - Echinochloa crus-galli & 3 & 1 & - & - & - & 0,8 \\
\hline Miotła zbożowa - Apera spica-venti & 3 & 1 & 15 & - & - & 3,8 \\
\hline Owies głuchy - Avena fatua & - & - & - & 6 & - & 1,2 \\
\hline Perz właściwy - Elymus repens & - & - & - & 1 & - & 0,2 \\
\hline \multicolumn{7}{|c|}{ Chwasty dwuliścienne - Dicotyledonous } \\
\hline Bodziszek porozcinany - Geranium dissectum & 8 & - & - & - & - & 1,6 \\
\hline Chaber bławatek - Centaurea cyanus & 3 & 2 & 4 & 2 & - & 2,2 \\
\hline Fiołek polny - Viola arvensis & 2 & - & - & - & - & 0,4 \\
\hline Gwiazdnica pospolita - Stellaria media & 1 & 1 & 1 & 1 & - & 0,8 \\
\hline Jasnota purpurowa - Lamium purpureum & - & - & - & 2 & 5 & 1,6 \\
\hline Komosa biała - Chenopodium album & 7 & 6 & - & 2 & 3 & 3,6 \\
\hline Mak polny - Papaver rhoeas & 1 & - & - & 4 & 4 & 1,8 \\
\hline Maruna bezwonna - Matricaria maritima subsp. inodora & - & - & 1 & 4 & - & 1,0 \\
\hline Ostrożeń polny - Cirsium arvense & - & - & - & - & 4 & 0,8 \\
\hline Przetacznik perski - Veronica persica & - & - & 8 & - & - & 1,6 \\
\hline Przymiotno kanadyjskie - Erigeron canadensis & 5 & - & - & - & - & 1,0 \\
\hline Przytulia czepna - Galium aparine & - & 7 & 1 & 10 & 4 & 4,4 \\
\hline Rdest powojowy - Fallopia convolvulus & 7 & 3 & - & - & 3 & 2,6 \\
\hline Rumian polny - Anthemis arvensis & 10 & - & - & 5 & 5 & 4,0 \\
\hline Tobołki polne - Thlaspi arvense & - & - & 1 & - & - & 0,2 \\
\hline Skrzyp polny - Equisetum arvense & - & 4 & - & - & - & 0,8 \\
\hline Razem - Total & 50 & 25 & 31 & 37 & 28 & 34,2 \\
\hline
\end{tabular}

Źródło: opracowanie własne - Source: own elaboration

Tabela 8. Różnorodność gatunkowa chwastów w łanie mieszanki zbożowej w gospodarstwach zróżnicowanych powierzchnią użytków rolnych $\left[\mathrm{szt} . / \mathrm{m}^{2}\right]$

Table 8. Weed species composition and number of weeds cereals mixture in farms differentiated on agricultural acreage $\left[\mathrm{number} / \mathrm{m}^{2}\right]$

\begin{tabular}{|c|c|c|c|c|c|c|}
\hline \multirow{2}{*}{ Gatunek - Weed species } & \multicolumn{5}{|c|}{ Grupa obszarowa gospodarstw - Group of area farm } & \multirow{2}{*}{$\begin{array}{c}\text { Średnio } \\
\text { Mean }\end{array}$} \\
\hline & $10-20$ & $21-30$ & $31-50$ & $51-100$ & $>100$ & \\
\hline 1 & 2 & 3 & 4 & 5 & 6 & 7 \\
\hline \multicolumn{7}{|c|}{ Chwasty jednoliścienne - Monocotyledonous } \\
\hline Miotła zbożowa-Apera spica-venti & 2 & - & 5 & 10 & - & 3,4 \\
\hline Owies głuchy - Avena fatua & - & - & 5 & - & - & 1,0 \\
\hline \multicolumn{7}{|c|}{ Chwasty dwuliścienne - Dicotyledonous } \\
\hline Bodziszek porozcinany - Geranium dissectum & 8 & - & - & - & - & 1,6 \\
\hline Chaber bławatek-Centaurea cyanus & - & 5 & 3 & 5 & 5 & 3,6 \\
\hline Fiołek polny - Viola arvensis & 2 & - & 15 & - & - & 3,4 \\
\hline Gwiazdnica pospolita - Stellaria media & 1 & - & - & 10 & - & 2,2 \\
\hline Komosa biała - Chenopodium album & 7 & 9 & 3 & 1 & - & 4,0 \\
\hline Mak polny - Papaver rhoeas & - & 5 & - & - & - & 1,0 \\
\hline Maruna bezwonna - Matricaria maritima subsp. inodora & - & - & - & - & 5 & 1,0 \\
\hline
\end{tabular}




\begin{tabular}{|c|c|c|c|c|c|c|}
\hline 1 & 2 & 3 & 4 & 5 & 6 & 7 \\
\hline Przetacznik perski - Veronica persica & 1 & 5 & 26 & - & - & 6,4 \\
\hline Przymiotno kanadyjskie - Erigeron canadensis & 5 & - & - & - & - & 1,0 \\
\hline Przytulia czepna - Galium aparine & - & 3 & 20 & 10 & 5 & 7,6 \\
\hline Rdest powojowy - Fallopia convolvulus & 7 & 5 & 24 & - & 5 & 8,2 \\
\hline Rumian polny - Anthemis arvensis & 10 & - & - & 5 & - & 3,0 \\
\hline Szarłat szorstki-Amaranthus retroflexus & - & - & - & - & 5 & 1,0 \\
\hline Tobołki polne - Thlaspi arvense & - & - & 3 & - & - & 0,6 \\
\hline Żółtlica drobnokwiatowa - Galinsoga parviflora & - & - & 20 & - & - & 4,0 \\
\hline Razem - Total & 43 & 32 & 124 & 41 & 25 & 53,0 \\
\hline
\end{tabular}

Źródło: opracowanie własne - Source: own elaboration

Tabela 9. Różnorodność gatunkowa chwastów w łanie kukurydzy w gospodarstwach zróżnicowanych powierzchnią użytków rolnych [szt. $/ \mathrm{m}^{2}$ ]

Table 9. Weed species composition and number of weeds in maize in farms differentiated on agricultural acreage [number $\left./ \mathrm{m}^{2}\right]$

Gatunek - Weed species

\begin{tabular}{|c|c|c|c|c|c|}
\hline \multicolumn{4}{|c|}{ Grupa obszarowa gospodarstw - Group of area farm } & \multirow{2}{*}{$\begin{array}{c}\text { Średnio } \\
\text { Mean }\end{array}$} \\
\hline $10-20$ & $21-30$ & $31-50$ & $51-100$ & $>100$ & . \\
\hline
\end{tabular}

Chwasty jednoliścienne - Monocotyledonous

\begin{tabular}{l|c|c|c|c|c}
\hline Chwastnica jednostronna - Echinochloa crus-galli & 1 & 25 & 19 & 7 & 2 \\
\hline Włośnica sina - Setaria pumila & - & - & - & 10,8 & - \\
\hline Perz właściwy - Elymus repens & - & - & 4 & 2,0 \\
\hline
\end{tabular}

Chwasty dwuliścienne - Dicotyledonous

\begin{tabular}{|c|c|c|c|c|c|c|}
\hline Bodziszek porozcinany - Geranium dissectum & 8 & 10 & 1 & 10 & - & 5,8 \\
\hline Chaber bławatek - Centaurea cyanus & - & - & 5 & 10 & 3 & 3,6 \\
\hline Fiołek polny - Viola arvensis & 1 & - & - & - & 16 & 3,4 \\
\hline Gwiazdnica pospolita - Stellaria media & - & - & - & 9 & 5 & 2,8 \\
\hline Jasnota purpurowa - Lamium purpureum & - & 5 & - & - & - & 1,0 \\
\hline Komosa biała - Chenopodium album & 7 & 5 & 7 & 15 & 10 & 8,8 \\
\hline Ostrożeń polny - Cirsium arvense & - & 4 & 1 & - & - & 1,0 \\
\hline Przetacznik perski - Veronica persica & 1 & - & 10 & - & 10 & 4,2 \\
\hline Przymiotno kanadyjskie - Erigeron canadensis & 5 & - & - & - & - & 1,0 \\
\hline Przytulia czepna - Galium aparine & - & - & 3 & 5 & 2 & 2,0 \\
\hline Rdest plamisty - Polygonum persicaria & - & - & - & - & 5 & 1,0 \\
\hline Rdest powojowy - Fallopia convolvulus & 7 & 7 & - & 3 & 8 & 5,0 \\
\hline Rumian polny - Anthemis arvensis & 10 & - & - & 5 & - & 3,0 \\
\hline Szarłat szorstki - Amaranthus retroflexus & - & - & - & 6 & - & 1,2 \\
\hline Tasznik pospolity - Capsella bursa-pastoris & 1 & - & - & - & 4 & 1,0 \\
\hline Żółtlica drobnokwiatowa - Galinsoga parviflora & - & - & - & - & 6 & 1,2 \\
\hline Razem - Total & 41 & 56 & 50 & 82 & 78 & 61,4 \\
\hline
\end{tabular}

Źródło: opracowanie własne - Source: own elaboration

stwierdzono występowanie 12 gatunków chwastów, przy czym w największym nasileniu: Ch. album, Viola arvensis, Polygonum convolvulus oraz E. crus-galli. W badaniach Sobiecha i wsp. (2018) w uprawie kukurydzy obserwowano liczne występowanie Ch. album oraz E. crus-galli, co zanotowała także Gołębiowska (2012). Wspomniane chwasty uznaje się za typowe i uciążliwe dla uprawy kukurydzy (Idziak i Woźnica 2009). Podaje się, że duża 
liczebność tych gatunków może być spowodowana wzrostem powierzchni uprawy kukurydzy oraz intensyfikacją produkcji roślinnej (Gołębiowska i wsp. 2015).

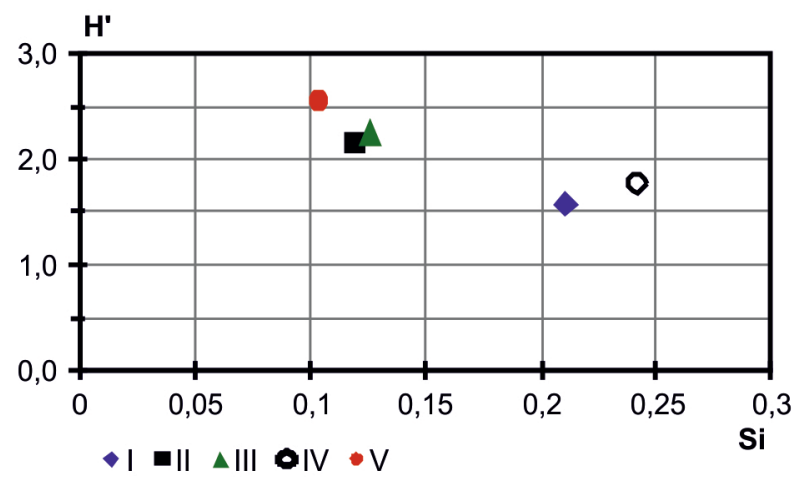

Rys. 2. Index bioróżnorodności Shannona-Wienera (H') i dominacji Simpsona (SI) w łanie pszenicy ozimej

Fig. 2. Shannon-Wiener's diversity index ( $\left.\mathrm{H}^{\prime}\right)$ and Simpson's dominance index (SI) for weed flora of winter wheat

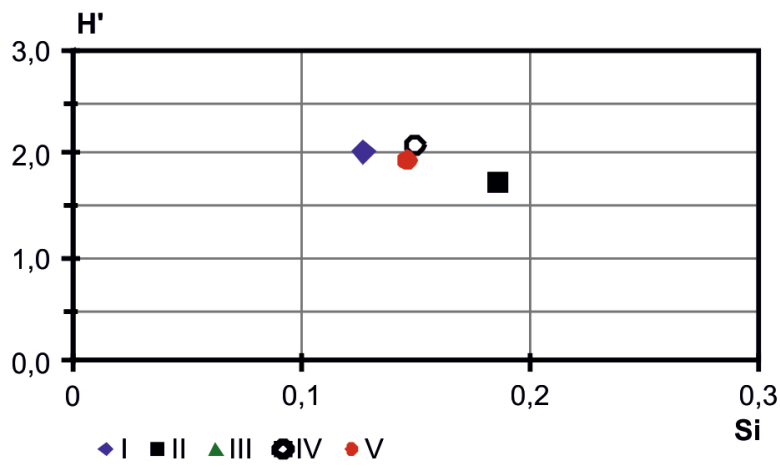

Rys. 4. Index bioróżnorodności Shannona-Wienera (H’) i dominacji Simpsona (SI) w łanie jęczmienia jarego

Fig. 4. Shannon-Wiener's diversity index (H') and Simpson's dominance index (SI) for weed flora of spring barley
Różnorodność gatunkowa flory segetalnej mierzona wskaźnikiem różnorodności Shannona-Wienera i indeksem dominacji Simpsona były zróżnicowane w zależności od

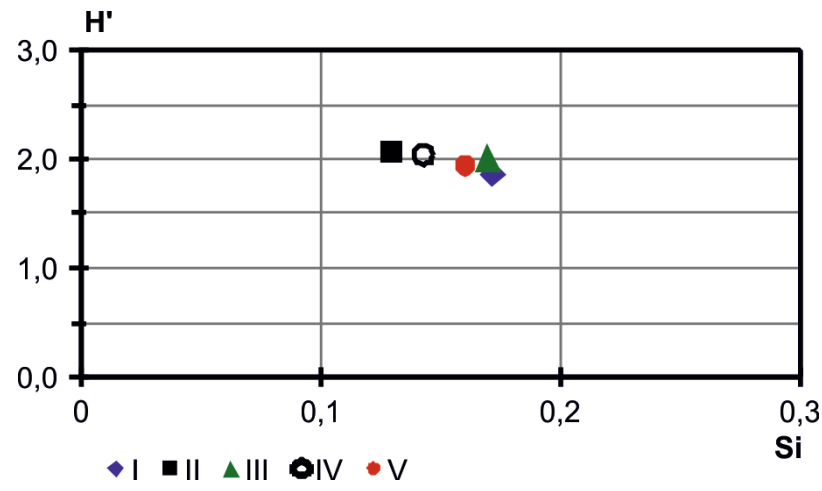

Rys. 3. Index bioróżnorodności Shannona-Wienera (H') i dominacji Simpsona (SI) w łanie pszenżyta ozimego

Fig. 3. Shannon-Wiener's diversity index (H') and Simpson's dominance index (SI) for weed flora of winter triticale

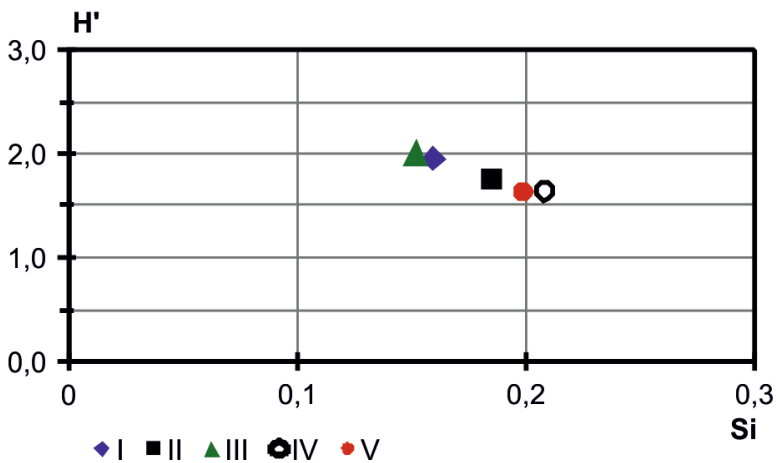

Rys. 5. Index bioróżnorodności Shannona-Wienera (H') i dominacji Simpsona (SI) w łanie mieszanki zbożowej

Fig. 5. Shannon-Wiener's diversity index (H') and Simpson's dominance index (SI) for weed flora of cereal mixture

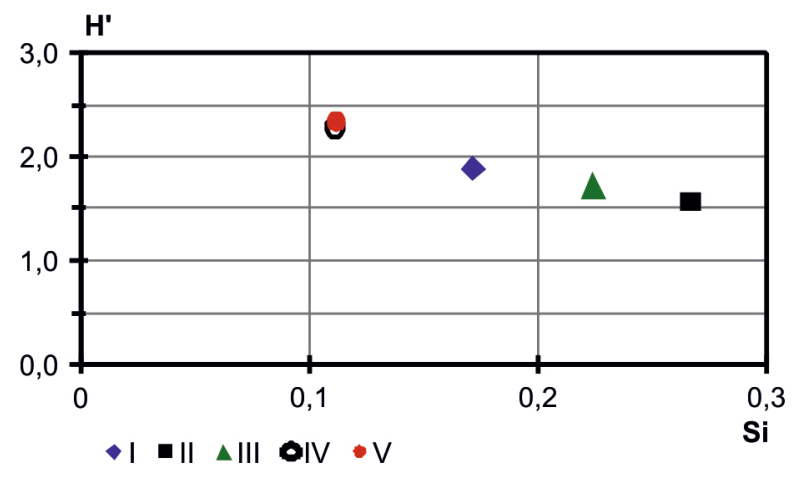

Rys. 6. Index bioróżnorodności Shannona-Wienera (H') i dominacji Simpsona (SI) w łanie kukurydzy

Fig. 6. Shannon-Wiener's diversity index (H') and Simpson's dominance index (SI) for weed flora of maize 
gatunku rośliny uprawnej oraz wielkości gospodarstwa (rys. 2-6). Wartości wskaźnika Shannona-Wienera użytego do oceny różnorodności florystycznej określają całościową różnorodność w poddawanej badaniom fitocenozie. Wyniki przedstawione na rysunkach 2-6, pokazują, że różnorodność biologiczna analizowanych zbiorowisk była zróżnicowana $\mathrm{w}$ zależności od gatunku badanej rośliny uprawnej oraz wielkości gospodarstwa.

W uprawie pszenicy ozimej jedynie gospodarstwo o najmniejszej powierzchni odbiegało od pozostałych, charakteryzując się stosunkowo niską wartością indeksu Shannona-Wienera $\left(\mathrm{H}^{\prime}=1,51\right)$ i wysoką wartością indeksu Simpsona (SI = 0,21), co wskazuje na wyraźną dominację w zbiorowisku jednego lub dwóch gatunków chwastów (Ch. album i A. arvensis). Gospodarstwo to jednocześnie charakteryzowało się najmniejszą liczbą oznaczonych gatunków chwastów (5 taksonów), ale także najuboższym składem gatunkowym flory segetalnej (40 sztuk).

Spośród badanych gatunków roślin uprawnych największą różnorodnością, ocenianą za pomocą wskaźnika Shannona-Wienera, charakteryzowało się zbiorowisko chwastów w uprawie pszenicy ozimej w gospodarstwach o powierzchni powyżej 100 ha $\left(\mathrm{H}^{\prime}=1,77\right)$.

W celu określenia równocenności, która opisuje udział poszczególnych gatunków w danym zbiorowisku zastosowano wskaźnik różnorodności Simpsona. Pozwala on ocenić prawdopodobieństwo spotkania dwóch osobników zaliczanych do jednego gatunku. Wartości tego wskaźnikawrokuprowadzeniaobserwacjibyłyzróżnicowane w poszczególnych uprawach. Wychodząc z założenia, że im wyższa jest wartość wspomnianego wskaźnika tym większa jest różnorodność ( 1 = maksymalna różnorodność) można zauważyć, że otrzymane wyniki pokazują zróżnicowanie zbiorowiska chwastów w poszczególnych uprawach. Najwyższe wartości indeksu dominacji stwierdzono dla jęczmienia jarego uprawianego $\mathrm{w}$ gospodarstwach o powierzchni w zakresie $31-50$ ha $(\mathrm{SI}=0,32)$ oraz dla kukurydzy uprawianej $\mathrm{w}$ gospodarstwach o powierzchni do 30 ha $(\mathrm{SI}=0,27)$ (rys. 6), co świadczy o dominacji pewnych gatunków chwastów (A. spica-venti, Veronica persica, E. crus-galli oraz Geranium dissectum).

\section{Wnioski / Conclusions}

1. W objętych analizą gospodarstwach skład gatunkowy zbiorowisk chwastów różnił się w zależności od wielkości gospodarstwa oraz rośliny uprawnej. Najbardziej zachwaszczone były łany pszenżyta ozimego i pszenicy ozimej, natomiast najmniej jęczmienia jarego i mieszanki zbożowej.

2. Różnorodność flory segetalnej towarzyszącej roślinom uprawnym była większa w zasiewach form ozimych niż jarych.

3. Najwięcej chwastów w łanach roślin uprawnych form ozimych stwierdzono w gospodarstwach największych obszarowo, natomiast najmniej w gospodarstwach do 20 ha użytków rolnych. Odwrotne relacje stwierdzono w uprawie jarych form gatunków roślin zbożowych.

4. Ocena różnorodności biologicznej flory segetalnej za pomocą wskaźników różnorodności Shannona-Wienera i dominacji Simpsona wykazała różnice pomiędzy poszczególnymi grupami gospodarstw. Zróżnicowane wartości wskaźników zbiorowisk chwastów są wynikiem stosunkowo dużej różnorodności gatunkowej we wszystkich grupach gospodarstw.

5. Najliczniej występującymi gatunkami chwastów $\mathrm{w}$ uwzględnionych $\mathrm{w}$ badaniach zasiewach roślin uprawnych były taksony: Ch. album, C. cyanus, A. arvensis, A. spica-venti, $G$. aparine, $F$. convolvulus oraz E. crus-galli.

\section{Podziękowanie / Acknowledgements}

Praca wykonana $w$ ramach realizacji zadania 2.3 Programu Wieloletniego Instytutu Uprawy Nawożenia i Gleboznawstwa - Państwowego Instytutu Badawczego w Puławach pt. „Wspieranie działań w zakresie ochrony i racjonalnego wykorzystania rolniczej przestrzeni produkcyjnej w Polsce oraz kształtowania jakości surowców roślinnych na lata 2016-2020".

\section{Literatura / References}

Berbeć A., Radzikowski P., Stalenga J., Feledyn-Szewczyk B., Hajdamowicz I., Stańska M. 2013. Ocena różnorodności flory segetalnej i owadów prostoskrzydłych w zbożach ozimych uprawianych w systemie ekologicznym i konwencjonalnym. [An assessment of weed flora and orthopteran diversity in winter cereals cultivated in organic and conventional systems]. Woda-Środowisko-Obszary Wiejskie 13 (4): 5-16.

Bojarszczuk J., Podleśny J., Nowak J. 2018. Ocena różnorodności zbiorowisk segetalnych w łanach roślin uprawnych w wybranych gospodarstwach w województwie lubelskim. [The assessment of the diversity of weed flora communities in crops cultivated in selected farms in Lubelskie voivodeship]. Progress in Plant Protection 58 (3): 216-223. DOI: 10.14199/ppp-2018-029.

Dobrzański A. 2007. Wpływ regulowania zachwaszczenia roślin ogrodniczych na różnorodność biologiczną. [The impact of weed management in horticultural crops on biodiversity]. Zeszyty Naukowe Wydziału Ogrodniczego, Wyższa Szkoła Ekonomiczno-Humanistyczna w Skierniewicach 7: 61-75. 
Dobrzański A. 2009. Biologiczne i agrotechniczne aspekty regulowania zachwaszczenia. Ekspertyza. Instytut Warzywnictwa, Skierniewice. Publikacja dostępna w serwisie: www.agengpol.pl, 24 ss.

Dobrzański A., Adamczewski K. 2009. Wpływ walki z chwastami na bioróżnorodność agrofitocenoz. [The influence of weed control on agrophytocenosis biodiversity]. Progress in Plant Protection/Postępy w Ochronie Roślin 49 (3): 982-995.

Duer I. 2002. Znaczenie chwastów i strategia ich ograniczania w gospodarstwie ekologicznym. W: Rolnictwo ekologiczne szansą na polską specjalność. Materiały szkoleniowe 86/02: 21-26, Instytut Uprawy Nawożenia i Gleboznawstwa, Puławy.

Feledyn-Szewczyk B. 2012. Ocena różnorodności zbiorowisk segetalnych w roślinach uprawianych w wybranych gospodarstwach ekologicznych w województwie lubelskim. [The assessment of the diversity of weed flora communities in crops cultivated in selected organic farms in Lublin province]. Journal of Research and Applications in Agricultural Engineering 57 (3): 63-72.

Feledyn-Szewczyk B., Duer I. 2006. Efektywność metod regulacji zachwaszczenia w jęczmieniu jarym uprawianym w różnych systemach produkcji. [Effectiveness of weed regulation methods in spring barley cultivated in different crop production systems]. Progress in Plant Protection/Postępy w Ochronie Roślin 46 (1): 45-52.

Giera A. 2012. Bioróżnorodność w wybranych gospodarstwach rolnych zlokalizowanych na obszarach szczególnie narażonych. [Biodiversity on farms located in nitrate vulnerable zones]. Zagadnienia Doradztwa Rolniczego 2: 79-103.

Gołębiowska H. 2012. Problemy ograniczania chwastów wieloletnich w uproszczonej uprawie kukurydzy w warunkach Dolnego Śląska. [Problems with the control of perennial weeds in a simplified cultivation system of maize crops in the conditions of Lower Silesia]. Progress in Plant Protection 52 (3): 556-562. DOI: 10.14199/ppp-2012-096.

Gołębiowska H., Snopczyński T., Domaradzki K., Rola H. 2015. Zmiany w zachwaszczeniu kukurydzy w południowo-zachodnim rejonie Polski w latach 1963-2013. [Changes in weed infestation in corn crops in southwestern region of Poland in 1963-2013 years]. Progress in Plant Protection 55 (3): 327-339. DOI: 10.14199/ppp-2015-057.

GUS 2018. Rocznik Statystyczny Rolnictwa 2018. Główny Urząd Statystyczny, Warszawa, 453 ss.

Idziak R., Woźnica Z. 2009. Ocena efektywności adiuwantów olejowego i mineralnego w mieszaninach herbicydów Callisto 100 SC i Maister 310 WG stosowanych w ochronie kukurydzy. [Evaluation of efficacy of oil and mineral adjuvants added to mixtures of herbicides Callisto $100 \mathrm{SC}$ and Maister 310 WG applied in maize]. Acta Scientiarum Polonorum, Agricultura 8 (1): 17-26.

Liszka-Podkowa A., Sowiński J. 2009. Skuteczność różnych metod odchwaszczania kukurydzy oraz pobranie makropierwiastków przez chwasty. [Efficacy of different weed control methods in maize and macronutrients uptake by weeds]. Fragmenta Agronomica 26 (3): $109-117$.

Orzech K., Rychcik B., Stępień A. 2011. Wpływ sposobów uprawy roli na zachwaszczenie i plonowanie jęczmienia jarego. [The influence of tillage systems on weed infestation and yield of spring barley]. Fragmenta Agronomica 28 (2): 63-70.

Rola H., Rola J. 2002. Progi szkodliwości chwastów w programach decyzyjnych ochrony roślin zbożowych. [Thresholds for weeds in decision support system programs in plant protection]. Progress in Plant Protection/Postępy w Ochronie Roślin 42 (1): $332-339$.

Sobiech Ł., Idziak R., Skrzypczak G., Szulc P., Grzanka M. 2018. Bioróżnorodność zachwaszczenia w uprawie kukurydzy na glebie płowej. [Biodiversity of weed flora in maize on lessive soil]. Progress in Plant Protection 58 (4): 282-287. DOI: 10.14199/ppp-2018039.

Staniak M., Księżak J., Bojarszczuk J. 2011. Zachwaszczenie kukurydzy w ekologicznym systemie uprawy. [Weed infestation of maize cultivated in organic farming]. Journal of Research and Applications in Agricultural Engineering 56 (4): 123-128.

Stupnicka-Rodzynkiewicz E., Stępnik K., Dąbkowska T., Łabza T. 2004. Różnorodność zbiorowisk chwastów w uprawach zbóż w Beskidach. [Diversity of cereal crops weed communities in the Beskidy mountains]. Fragmenta Agronomica 4 (84): $45-53$.

Waligóra H., Skrzypczak W., Szulc P. 2009. Wpływ sposobu pielęgnacji na zachwaszczenie kukurydzy cukrowej. [Influence of sweet maize cultivation method on the weed infestation]. Journal of Research and Applications in Agricultural Engineering 54 (4): $148-152$.

Woźnica Z. 2008. Herbologia. Podstawy biologii, ekologii i zwalczania chwastów. Powszechne Wydawnictwo Rolnicze i Leśne, Poznań, 430 ss. ISBN 978-83-09-99007-9.

Zanin G., Mosca G., Catizone P. 1992. A profile of the potential flora in maize fields of the Po valley. Weed Research 32 (5): $407-418$. DOI: $10.1111 /$ j.1365-3180.1992.tb01902.x. 